\title{
Arbutoid mycorrhizas of the genus Cortinarius from Costa Rica
}

\author{
K. Kühdorf ${ }^{1}$ • B. Münzenberger ${ }^{1}$ - D. Begerow ${ }^{2}$ J. Gómez-Laurito ${ }^{3}$ • R. F. Hüttl ${ }^{4,5}$
}

Received: 27 November 2015 / Accepted: 9 February 2016 /Published online: 11 March 2016

(C) The Author(s) 2016. This article is published with open access at Springerlink.com

\begin{abstract}
Arbutoid mycorrhizas of Comarostaphylis arbutoides (Arbutoidea, Ericaceae) from neotropical montane forests are rarely described. To date, only mycorrhizal associations with the fungal species Leccinum monticola, Leotia lubrica and Sebacina sp. are known from literature. The genus Cortinarius is one of the most species-rich ectomycorrhizal taxa with over 2000 assumed species. In this study, two sites in the Cordillera de Talamanca of Costa Rica were sampled, where Com. arbutoides is endemic and grows together with Quercus costaricensis. Using a combined method of rDNA sequence analysis and morphotyping, 33 sampled mycorrhizal systems of Cortinarius were assigned to the subgenera Dermocybe, Phlegmacium and Telamonia. Specific plant primers were used to identify the host plant. Here, we present the phylogenetic data of all found Cortinarii and describe four of the arbutoid mycorrhizal systems morphologically and anatomically.
\end{abstract}

J. Gómez-Laurito is deceased

K. Kühdorf

Katja.Kuehdorf@zalf.de

1 Leibniz Centre for Agricultural Landscape Research (ZALF), Institute for Landscape Biogeochemistry, Eberswalder Straße 84, 15374 Müncheberg, Germany

2 Ruhr-University of Bochum, AG Geobotany, Universitätsstraße 150, 44780 Bochum, Germany

3 University of Costa Rica, Escuela de Biología, San José CP 11501-2060, Costa Rica

4 Brandenburg University of Technology Cottbus-Senftenberg, Chair of Soil Protection and Recultivation, Box 101344, 03013 Cottbus, Germany

5 German Research Centre of Geosciences Potsdam (GFZ), Telegrafenberg, 14473 Potsdam, Germany
Keywords Anatomy · Central America · Morphology · Secondary cloud forest

\section{Introduction}

Comarostaphylis arbutoides is a tropical woody plant of Central America, occurring in dry oak-pine and cloud forests, as well as in the páramo at an elevation of c. 2500 3430 m a.s.l. Together with Arbutus and Arctostaphylos, it belongs to the ericaceous subfamily Arbutoidea, which are known to form arbutoid mycorrhizas with ectomycorrhizal fungi (Molina and Trappe 1982). Although, Bidartondo and Bruns (2001) infer that Com. arbutoides forms arbutoid mycorrhizas with diverse species of Basidiomycetes and Ascomycetes, only mycorrhizal associations with Leccinum monticola, Sebacina sp. and Leotia cf. lubrica have been described so far (Osmundson et al. 2007; Kühdorf et al. 2014, 2015). However, typical as well as presumable ectomycorrhizal forming species of the genera Cortinarius, Hysterangium, Laccaria, Tricholoma and Phaeocollybia, have also been mentioned from the páramo by Halling and Mueller (1999). Therefore, further mycorrhizal associations with other fungal species for Com. arbutoides can be assumed.

The genus Cortinarius is assumed to be the species-richest genus of Agaricales, containing over 2000 species (Garnica et al. 2005) with a worldwide distribution (Peintner et al. 2004). The taxonomy of Cortinarius is largely based on macromorphological characters, spore morphology as well as on chemical characters (Brandrud 1996). The subdivision of Cortinarius into subgeneric units causes many problems, induced by high morphological variation within species, as well as the different weighting of morphological characters by different taxonomists (Peintner et al. 2004). However, 
molecular investigation of the genus Cortinarius is just at the beginning (Liimatainen 2013; Zotti et al. 2014). As proposed by Peintner et al. (2004), studies should, first of all, focus on natural units (e.g. sections), bringing DNA sequence data as well as morphological and ecological data in accordance, as already done by several authors (e.g. Garnica et al. 2009, 2011; Suárez-Santiago et al. 2009; Niskanen et al. 2013a, b; Dima et al. 2014; Stensrud et al. 2014; Liimatainen et al. 2015).

Cortinarius is an important ectomycorrhizal fungal genus associated with trees, shrubs and a number of herbaceous plants of many different plant families (Liimatainen 2013), whereby also host specificity occurs (e.g. Brandrud 1996; Garnica et al. 2003; Frøslev et al. 2007; Niskanen et al. 2011; Liimatainen 2013). Based on fruit body collections, Halling and Mueller (1999; 2005), Mueller et al. (2006) and Ammirati et al. (2007) have reported and/or described 18 different Costa Rican Cortinarii. These species were collected in the Talamanca mountain range of Costa Rica, where Comarostaphylis and Quercus trees occur.

In our samples collected in the Cerro de la Muerte (Cordillera de Talamanca, Costa Rica) several different Cortinarius species formed mycorrhizas with Com. arbutoides and Quercus sp. The genus Cortinarius was identified using molecular methods such as large subunit (LSU) and internal transcribed spacer (ITS) sequencing as well as phylogenetic analysis. Plant primers were used to sequence the ITS region of the host plant from the same mycorrhizal system as used for fungal analysis. According to Agerer (1991), we present a morphological and anatomical description of four cortinarioid mycorrhizal systems associated with Com. arbutoides.

\section{Materials and methods}

\section{Site location and sampling}

Sampling was conducted in a secondary cloud forest around the Mountain Cerro de la Muerte (3491 m a.s.1.) in the Cordillera de Talamanca of Costa Rica, $54 \mathrm{~km}$ southeast of the capital city of San José. Site I (Estación Biologíca de la Muerte; $3100 \mathrm{~m}$ a.s.1.; $9^{\circ} 33^{\prime} \mathrm{N}, 83^{\circ} 45^{\prime} \mathrm{W}$ ) is dominated by $Q$. costaricensis mixed with solitary individuals of Com. arbutoides. At site II (Reserva Forestal Los Santos; 3300 m a.s.1.; $9^{\circ} 34^{\prime} \mathrm{N}, 83^{\circ} 45^{\prime} \mathrm{W}$ ), Com. arbutoides itself is the dominating species, mixed with a few isolated Q. costaricensis. Members of the Araliaceae (Schefflera and Oreopanax); Cunoniaceae (Weinmannia); Ericaceae (Cavendishia, Disterigma and Vaccinium); Poaceae (Chusquea); Primulaceae (Myrsine) and Winteraceae (Drimys) form the understory vegetation.
Fine root systems of Com. arbutoides were collected during the rainy seasons in October 2010 and 2011. For this, a soil corer (diameter $3 \mathrm{~cm}$; length $40 \mathrm{~cm}$ ) was used at distances of 50 and $100 \mathrm{~cm}$ from the trunk. At the University of Costa Rica, turgid and apparently healthy morphotypes were sorted out using a stereomicroscope. Systems with the same morphological features (e.g. colour, hydrophobicity presence, emanating elements and rhizomorphs) were assigned to one morphotype. For further analyses, the morphotypes were preserved in $2 \%$ glutaraldehyde with a $0.1 \mathrm{M}$ sodium cacodylate buffer (Münzenberger et al. 2009) for light microscopy or dried on silica gel for DNA extraction, respectively. Identification of each morphotype is based on their respective sequence type. Within these 2 years a total of 60 soil cores were taken and analysed. The genus Cortinarius was proven genetically in 23 soil cores.

\section{Molecular analyses}

Genomic DNA was isolated from one unramified root tip per morphotype, using the DNeasy Plant Mini Kit (QIAGEN, Hilden, Germany) following the manufacturer's recommendations. To identify the mycorrhizal fungi at both family and species level, PCR amplification and sequencing of the internal transcribed spacer (ITS) region and the ribosomal nuclear large subunit (LSU) were performed. Here, the primer combinations ITS1F/ITS4 (Gardes and Bruns 1993; White et al. 1990) as well as LR0R/LR5 (Moncalvo et al. 2000) were used. In order to identify the plant from mycorrhizal root tips without coamplifying fungal DNA the angiosperm-specific ITS primer pair ITS-5A/ITS-241r was amplified (Osmundson et al. 2007). Sequencing service was facilitated by GATC Biotech AG (Konstanz, Germany). A total of 399 root tips were analysed genetically, of which 33 were identified as members of the genus Cortinarius. All sequences were deposited in NCBI GenBank under the accession numbers KM456990-KM457022 (ITS), KM457023-KM457055 (LSU), KF419121 (Com. arbutoides) and KM978077 (Quercus sp.).

Sequences were analysed and edited using Chromas Lite v2.01 software (http://technelysium.com.au). Identity of obtained sequence data was confirmed by BLASTn search against the NCBI database (http://www.ncbi.nlm.nih.gov/) and the database UNITE (Kõljalg et al. 2005; http://unite.ut. ee/). For phylogenetic analysis at species level, the datasets of ITS sequences provided by Peintner et al. (2004), Garnica et al. (2005) and Ammirati et al. (2007) were used. The dataset was complemented by best match results obtained by NCBI and UNITE blast search for each sequence. Alignment was performed with MAFFT v7 (Katoh et al. 2002) using the FFTNS-2 alignment algorithm. To estimate phylogenetic relationships, maximum likelihood and Bayesian approaches were applied. Maximum likelihood analyses were performed using 
RAxML (v7.7.1; Stamatakis 2006) in a parallelized version supplied by RAxML BlackBox (Stamatakis et al. 2008) with trees inferred from 100 rapid bootstrap analyses as starting trees in a heuristic search for the tree with the highest likelihood. GTRCAT was used in the heuristic search and the final evaluation of the best tree found was based on the GTR + Gamma model. The Bayesian analysis was performed using MrBayes v3.2.1 (Ronquist et al. 2012) on an iMac (2.9 GHz Quad-Core Intel Core i5). The GTR + Gamma model was in effect and four chains in two parallel runs were performed for $2,000,000$ generations, sampling every 1000 . Analyses were performed until average standard deviation of split frequencies was $<0.01$ and stationarity was checked using Tracer v1. 6.1 (Rambaut et al. 2014). The first 50,000 trees were discarded before calculating the posterior probabilities. The potential scale reduction factor (PSRF) values for all inferences were $\sim 1.0$, indicating a good posterior probability distribution sample.

\section{Microscopy}

The morphological and anatomical description of the mycorrhizas was carried out according to Agerer (1987-2012; 1991), and the online key of DEEMY (Agerer and Rambold 2004-2015). Anatomical studies are based on multiple arbutoid mycorrhizal systems. Drawings were performed with an interference contrast microscope (BX50F-3, Olympus Corporation, Tokyo, Japan) connected with a drawing tube. All drawings were done in thousandfold magnification.

For semi-thin sections, the mycorrhizas were fixed with $2 \%$ glutaraldehyde in $0.1 \mathrm{M}$ sodium cacodylate buffer $(\mathrm{pH}$ 7.2) at room temperature until further processing. Thereafter, six washes in $0.1 \mathrm{M}$ sodium cacodylate buffer were performed. Samples were postfixed in $1 \%$ osmium tetroxide in the same buffer for $1 \mathrm{~h}$ under light exclusion at room temperature. After six washes in double-distilled water, samples were dehydrated by immersion for $15 \mathrm{~min}$ in 25, 50, 70 and $95 \%$ acetone and three times for $1 \mathrm{~h}$ in $100 \%$ acetone, respectively. The mycorrhizal tips were embedded in Spurr's plastic (Spurr 1969) and sectioned with a diamond knife on an Ultracut Reichert Ultramicrotome (W. Reichert-LABTEC, Wolfratshausen, Germany). The sections (0.5- $\mu \mathrm{m}$ thick) were stained with crystal violet and investigated using a light microscope (Zeiss Axioskop 50, Oberkochen, Germany).

\section{Results}

\section{Phylogenetic analysis}

A total of 399 root tips were analysed genetically, of which 33 were assigned to the genus Cortinarius after sequence comparison with BLASTn in the NCBI database and UNITE. In
NCBI, best matches were mainly received with samples originally from North America, whereas comparison in UNITE almost exclusively resulted in European species (Tab. 1). In NCBI, 11 samples (KKM 109, KKM 117, KKM 149, KKM 167, KKM 198, KKM 204, KKM 298, KKM 335, KKM 407, KKM 429, KKM 437) achieved their highest match with no further identified Cortinarius sp. or Cortinariaceae samples, whereby this was the case only for KKM 432 in UNITE. The highest identity match in NCBI (100\%) is obtained by KKM 144 with Cortinarius comarostaphylii from Costa Rica; in UNITE $C$. leucophanes from Finland is the closest match (99\%) for this sample. KKM 132 achieved the lowest identity match in both databases ( 89 as well as $88 \%$ ) with Cortinarius exlugubris from New Zealand and Cortinarius terpsichores from Sweden, respectively.

The Bayesian and RAxML phylogenies, generated by ITS sequences are concordant. Both trees show the same grouping structure, supported by mainly higher posterior probabilities (PP) in the Bayesian analysis and lower bootstraps (BS) in the RAxML analysis (Fig. 1). Within the genus Cortinarius, the 33 samples can be assigned to three different subgenera: Dermocybe, Phlegmacium and Telamonia.

Around half of the analysed cortinarioid sequences belong to the Dermocybe subgenus (PP 1/BS 91), whereas 13 samples are assigned to subgroup "Dermocybe I" (PP 1/BS 100), and a further two samples (KKM 149, KKM 429) to subgroup "Dermocybe II" (PP 0.99/BS 73) (Fig. 1). The samples KKM 132 and KKM 144 are assigned to subgenus Phlegmacium, but can be found in two different clades. There, KKM 144 is grouped in a very well-supported cluster (PP 1/BS 100), whereas the cluster with KKM 132 received a good PP (0.93), but a weak BS support (53). The remaining 16 cortinarioid samples are assigned to the subgenus Telamonia and are distributed amongst three very well-supported clusters (PP 1/BS 96 to 100) as shown in Fig. 1.

Except for the telamonioid samples KKM 198, KKM 373 and KKM 376, where Quercus sp. was proven as host plant (Fig. 1), all mycorrhizal systems of the cortinarioid samples are formed with Com. arbutoides.

\section{Morpho-anatomical descriptions of arbutoid mycorrhizas formed by various Cortinarius sp. species with the Ericaceae Comarostaphylis arbutoides}

Of the 33 sequence types, four morphotypes were described in detail as, here, sufficient mycorrhizal materials were available. Assignment to the respective subgenus is based on phylogenetic analysis (Fig. 1).

Identification key for the cortinarioid mycorrhizas:

1 Mycorrhizal system usually not silvery, but densely stringy; older parts of mantle not transparent; 


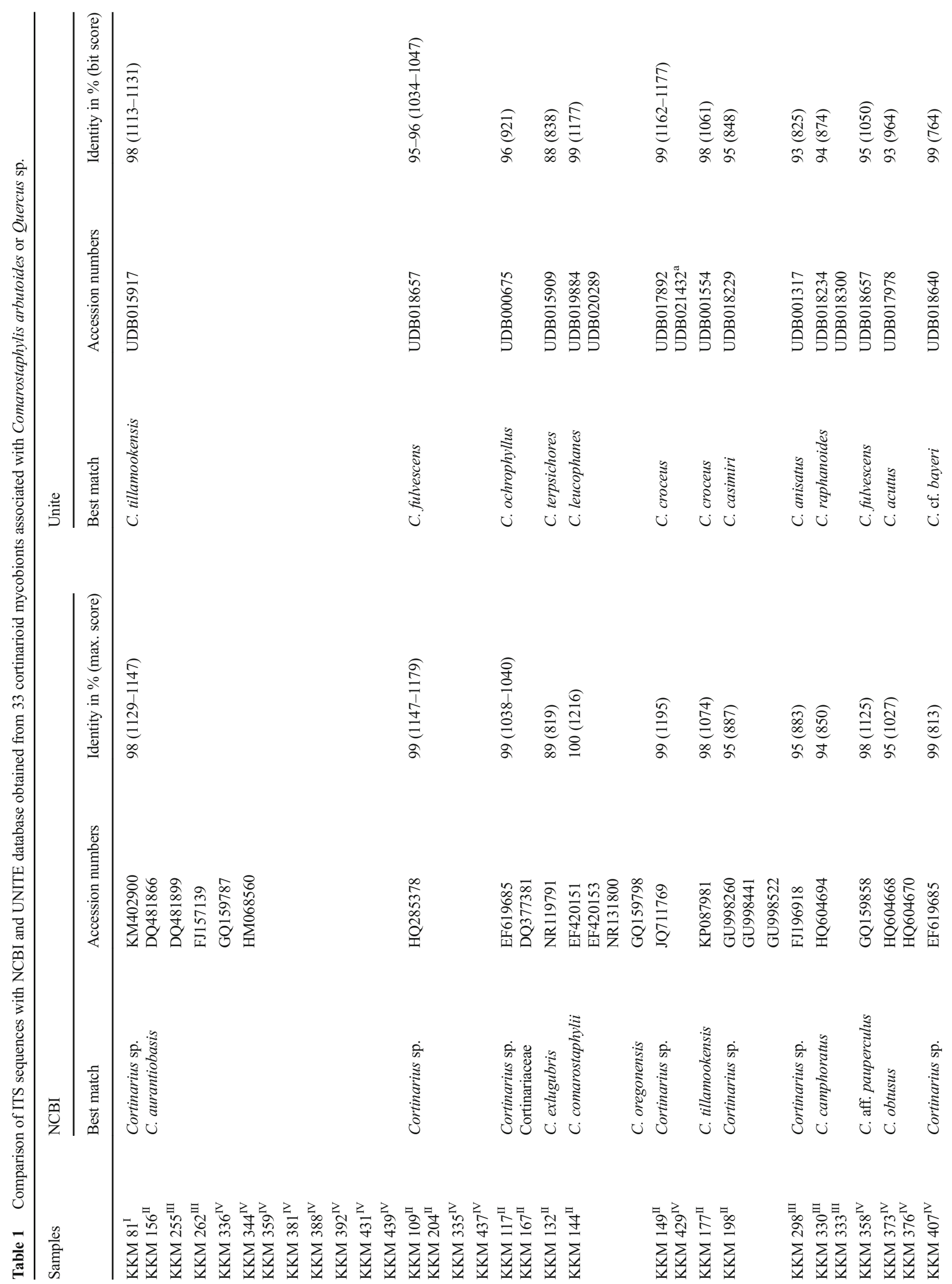




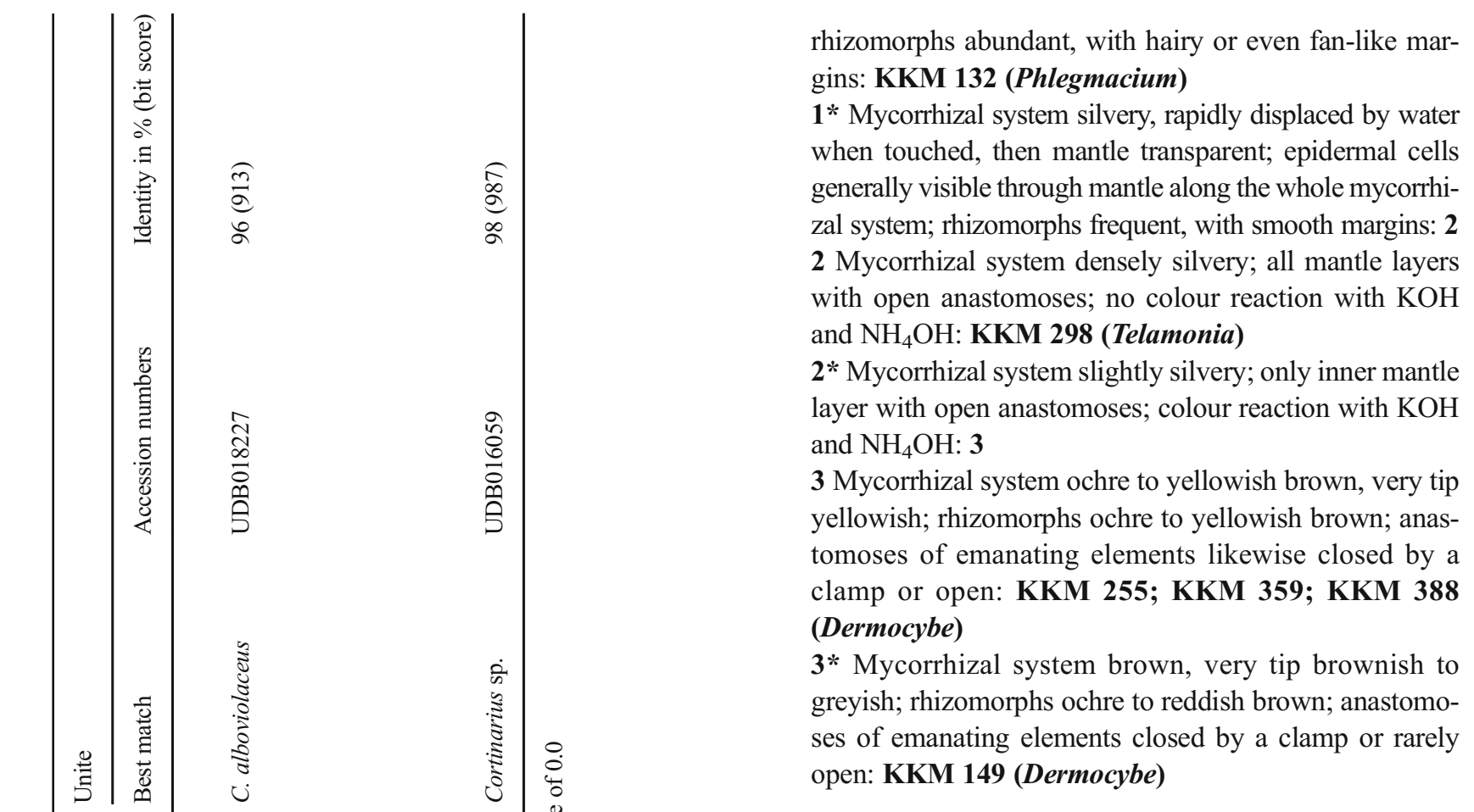

\section{KKM 132 (Phlegmacium) + Com. arbutoides}

Morphological characters (Fig. 2a) Mycorrhizal systems irregularly pinnate to dichotomous, with $0-1$ orders of ramification, systems abundant and dense, up to $6.8 \mathrm{~mm}$ long, strongly hydrophobic, of medium distance fringe exploration type. Main axes $0.3-0.5 \mathrm{~mm}$ diameter. Unramified ends sinuous to tortuous, not inflated, cylindric, up to 1.1 (2.1) $\mathrm{mm}$ long and $0.2-$ $0.3 \mathrm{~mm}$ diameter; mantle ochre to brownish, very tip ochre to yellowish, older parts dark brown and mycorrhizas not carbonising. Surface of unramified ends densely stringy, not smooth, very tip transparent and epidermal cells visible through mantle, older parts of mantle not transparent and occasionally, very tip partly silvery due to enclosed air. Rhizomorphs abundant, up to $0.12 \mathrm{~mm}$ diameter, roundish to flat in cross-section, emanating from all parts of the mycorrhiza, connection oblique, distal rhizomorphs connected over a long distance with mantle surface, growing into soil or organic layers, ochre to brownish, repeatedly ramified into smaller filaments, with hairy or even fan-like margins; rhizomorphs appear very wiry to brittle and are frequently found in short broken fragments around the mycorrhizal systems. Cystidia lacking. Sclerotia not observed.

Anatomical characters of the mantle in plan views (Fig. 2c-e) Mantle lacks cells densely filled with oily droplets or brownish content, blue granules, needle-like contents, matrix, crystals and exudated pigments, as well as cystidia. Outer mantle layers densely plectenchymatous, hyphae irregularly to somewhat star-like arranged, rarely ramified, some hyphae in bundles, without any special pattern (type B, Agerer 1991) 


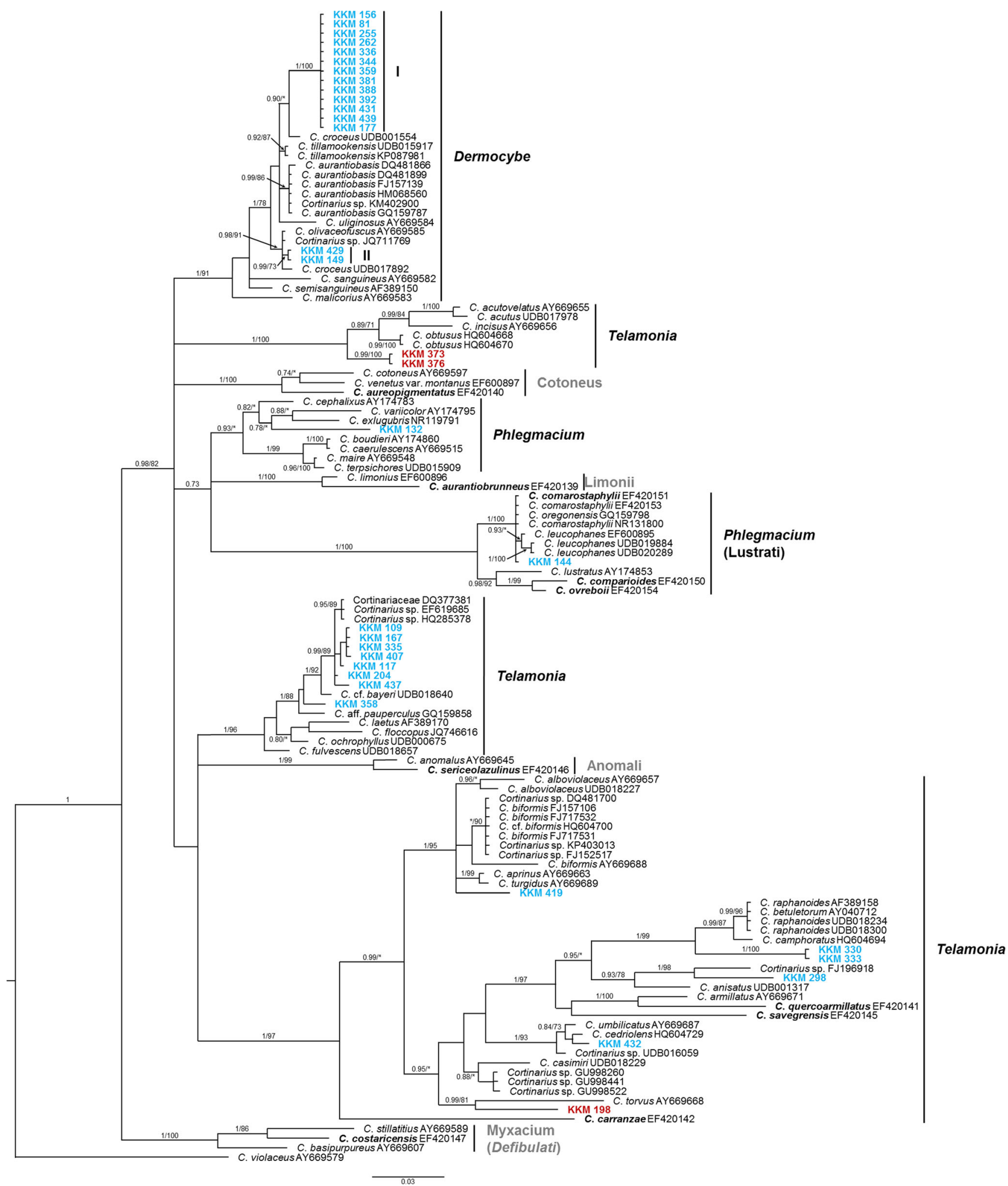

Fig. 1 Phylogenetic relationship of 33 cortinarioid mycobionts associated with Comarostaphylis arbutoides (blue) or Quercus sp. (red) within selected representatives of the genus Cortinarius. Phylogram was obtained from Bayesian analysis based on ITS sequences. Branch support values were calculated as posterior probability from 2,000,000 generations of Bayesian analysis (first number), and as bootstrap support from RAxML analysis (second number). Values below $70 \%$ are indicated with asterisks or omitted. The phylogram was rooted with Cortinarius violaceus. Costa Rican Cortinarius species from a previous study are marked in bold (Ammirati et al. 2007). Assignment to taxonomic units according to Peintner et al. (2004), Garnica et al. (2005), and Ammirati et al. (2007) 
Fig. 2 Arbutoid mycorrhiza of Cortinarius sp.-

Comarostaphylis arbutoides (sample KKM 132, subgenus Phlegmacium). a Habit of the phlegmacioid mycorrhiza with ochre to brownish coloured mantle, densely stringy mantle surface and ochre to brownish rhizomorphs; bar $=0.5 \mathrm{~mm}$. b Semi-thin section of phlegmacioid mycorrhiza with hyphal mantle $(H M)$, Hartig net $(H N)$ and intracellular hyphae $(i H), b a r=20 \mu \mathrm{m}$. c-h Plan view of different mantle layers and emanating elements of the phlegmacioid mycorrhiza; bar $=10 \mu \mathrm{m}$. c Outer mantle layer with densely and irregularly arranged hyphae, hyphae with clamps. d Middle mantle layer with densely arranged hyphae, some hyphae in bundles, forming ring-like structures. e Inner mantle layer with densely arranged hyphae; hyphae irregular in shape. f Emanating hyphae with open anastomosis and backwards-oriented ramification. g Rhizomorph with open anastomosis (asterisk). h Hyphae of rhizomorphs with backwards-oriented clamps (arrowheads), open anastomoses and acute as well as backwardsoriented ramifications
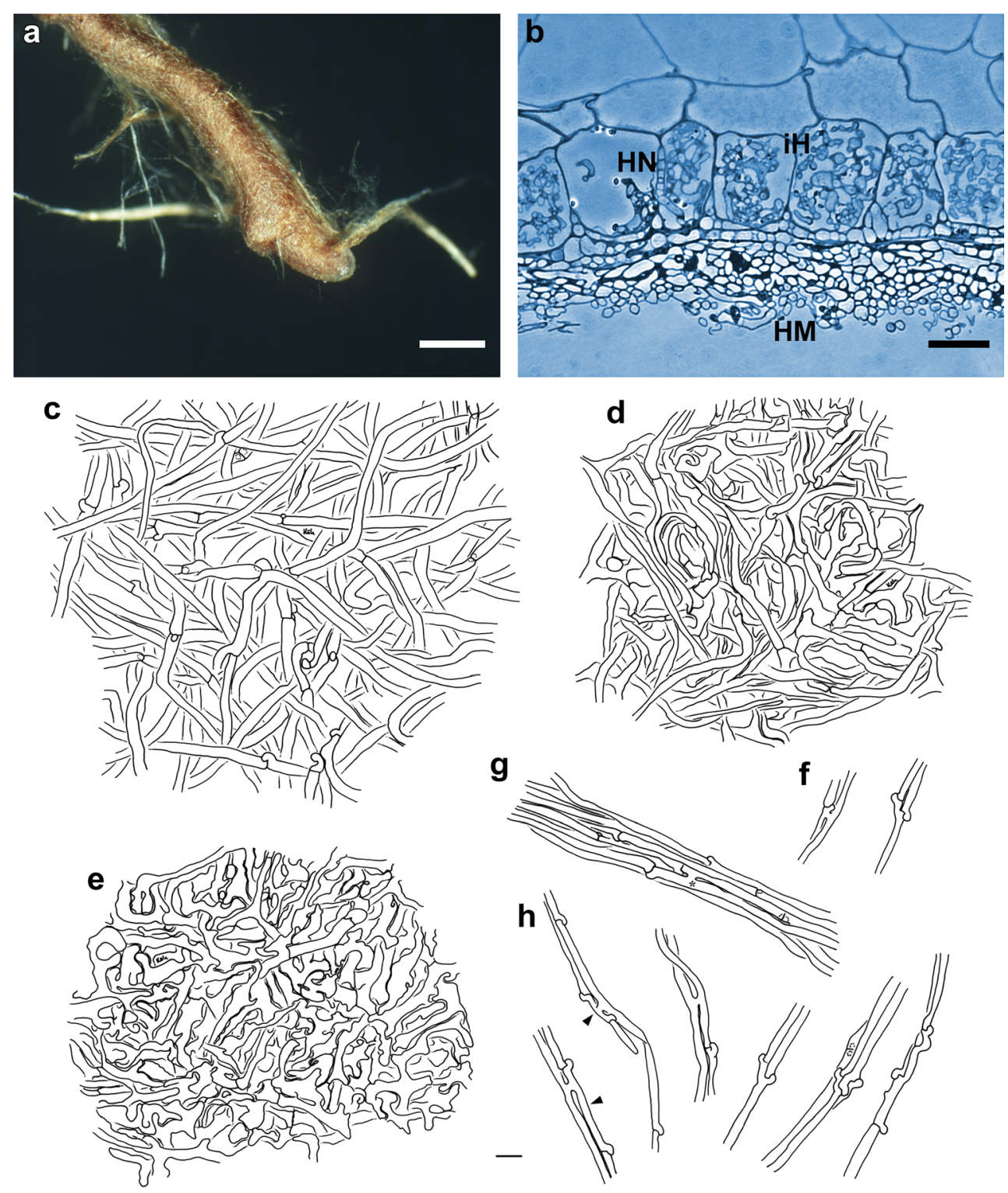

and yellow; hyphae (17) 25-39 (57) $\mu \mathrm{m}$ long, 2.7-4.4 $\mu \mathrm{m}$ in diameter, cells walls $0.3(0.4) \mu \mathrm{m}$ thick; hyphae with clamps and constricted at septa, septa as thick as cell walls. Middle mantle layers densely plectenchymatous, hyphae in bundles, forming ring-like structures, hyphae 7-39 (50) $\mu \mathrm{m}$ long, 1.6$4.6(6.4) \mu \mathrm{m}$ in diameter, cell walls $(0.2) 0.3-0.4 \mu \mathrm{m}$ thick, smooth and yellow; hyphae rarely septate, clampless and constricted at septa, septa as thick as cell walls. Inner mantle layers densely plectenchymatous, hyphae irregular in shape, hyphae (4) 8-27 (63) $\mu \mathrm{m}$ long, 1.8-6.8 (8.3) $\mu \mathrm{m}$ in diameter, cell walls $0.3-0.4 \mu \mathrm{m}$ thick, smooth and yellow; septa not observed. Very tip like other parts of the mantle.

Anatomical characters of emanating elements (Fig. 2f-h) Lacking are gelatinized hyphae, matrix, rhizomorphal nodia, simple septa, intrahyphal hyphae, crystals, brownish substances and secreted pigments; elbow-like protrusions not observed. Rhizomorphs undifferentiated, hyphae loosely interwoven and of uniform diameter (type A/B, Agerer and Rambold 2004-2015); hyphae smooth, cells (10) 65$113 \mu \mathrm{m}$ long, 2.4-3.8 $\mu \mathrm{m}$ diameter and cell walls $0.3-$ $0.4 \mu \mathrm{m}$; ramification backwards-oriented or acute, one or two hyphal diameter below the septum and ramifications one side branch at septum; septa with clamps, constricted at septa, backwards-oriented clamps observed only twice and septa as thick as hyphal walls; anastomoses frequent and open with a short bridge, bridge thinner or as thick as hyphae, cell walls of anastomoses as thick as remaining walls. Emanating hyphae straight to wavy, smooth, surface occasionally with

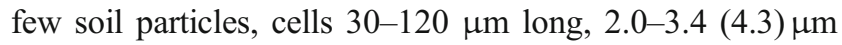


diameter, cell walls $0.3 \mu \mathrm{m}$, and distal ends of hyphae simple; ramification backwards-oriented or acute, with one side branch at septum, one or two hyphal diameter below the septum; septa with clamps, constricted at septa, backwardsoriented clamps not observed and septa as thick as hyphal walls; anastomoses rare and open with a short bridge, bridge as thick as hyphae, cell walls of anastomoses as thick as remaining walls. Cystidia not found.

Anatomical characters of longitudinal section (Fig. 2b) Mantle plectenchymatous, 13-27 $\mu$ m thick. Mantle of very tip plectenchymatous, 16-20 $\mu \mathrm{m}$ thick. Epidermal layer with intracellular hyphae and epidermal cells radially oval to eliptic; Hartig net around epidermal cells para-epidermal in one row and hyphal cells roundish to cylindrical. Tannin cells are lacking.

Colour reactions with different reagents (mantle preparations and emanating elements) Cotton blue: hyphae blue or greenish; toluidine blue: hyphae blue to violet. No reaction was observed with: acetic acid, ethanol $70 \%, \mathrm{Fe}(\mathrm{II}) \mathrm{SO}_{4}$, guaiac, $\mathrm{KOH} 10 \%$, lactic acid, Lugol's solution, Melzer's reagent, $\mathrm{NH}_{4} \mathrm{OH}$ conc., sulpho-vanillin, $\mathrm{H}_{2} \mathrm{SO}_{4}$.

Reference specimen Costa Rica, province of San José, canton of Pérez Zeledón, at mountain Cerro de la Muerte, Reserva Forestal Los Santos (3300 m a.s.l.; precipitation c. $2812 \mathrm{~mm} /$ year; inceptisol (USDA)), in a secondary cloud forest with Q. costaricensis, soil core exc., myc. isol. Katja Kühdorf; KKM 132, 12 October 2010; mycorrhiza deposited by B. Münzenberger (ZALF Müncheberg, Germany).

\section{KKM 298 (Telamonia) + Com. arbutoides}

Morphological characters (Fig. 3a) Mycorrhizal systems irregularly pinnate to dichotomous, with $0-4$ orders of ramification, systems nest-like, forming hyphal mats, up to $8.4 \mathrm{~mm}$ long, strongly hydrophobic, of medium distance fringe exploration type. Main axes $0.3-0.4 \mathrm{~mm}$ diameter. Unramified ends bent or sinuous, not inflated, cylindric, up to 1.8 (3) $\mathrm{mm}$ long, $0.2-0.3(0.4) \mathrm{mm}$ diameter; mantle and very tip white and yellowish to ochre, older parts light orange, not carbonising. Surface of unramified ends densely stringy or forming rings, not smooth, fan-like cottony between side branches and main axis, densely silvery by enclosed air, rapidly displaced by water when touched, then mantle transparent and epidermal cells visible through mantle. Rhizomorphs frequent, up to $0.25 \mathrm{~mm}$ diameter; flat in cross-section, emanating from all parts of the mycorrhiza, connection oblique, distal rhizomorphs connected over a long distance with mantle surface, growing into soil or organic layers, white, repeatedly ramified into smaller filaments, with smooth margins. Cystidia lacking. Sclerotia not observed.
Anatomical characters of the mantle in plan views (Fig. 3c-e) Mantle lacks cells densely filled with oily droplets or brownish content, blue granules, needle-like contents, crystals and exudated pigments, matrix, as well as cystidia. Outer mantle layers densely plectenchymatous, hyphae irregularly to somewhat star-like arranged, occasionally ramified, without any special pattern, often with bundles of parallel hyphae (type B, Agerer 1991) and colourless, with few soil particles; hyphae smooth and cylindric, hyphae (32) 85-140 $\mu \mathrm{m}$ long, (2.7) 3.3-5.8 (6.6) $\mu \mathrm{m}$ diameter, cell walls $0.2-0.3 \mu \mathrm{m}$ thick; hyphae with clamps, constricted at septa, septa as thick as cell walls and anastomoses open, with a short bridge, bridge thinner or as thick as hyphae. Middle mantle layers densely plectenchymatous, hyphae irregularly interwoven, some hyphae in bundles, hyphae (14) 20-32 (50) $\mu \mathrm{m}$ long, (1.9) 2.3 $4.3(5.2) \mu \mathrm{m}$ in diameter, cell walls $0.3 \mu \mathrm{m}$ thick, irregularly inflated, smooth and colourless; hyphae with simple septa, occasionally with clamps, constricted at septa and septa as thick as cell walls and anastomoses open or closed, with short bridge, bridge thinner or as thick as hyphae. Inner mantle layers densely plectenchymatous, hyphae in bundles, forming ring-like structures, hyphae uneven in diameter, some hyphae epidermoid, sometimes ampullate at one side of septum and hyphae up to (9) 20-115 (200) $\mu \mathrm{m}$ long, 2.4-5.3 $\mu \mathrm{m}$ in diameter, cell walls $0.3 \mu \mathrm{m}$ thick and colourless; hyphae with simple septa, rarely with clamp connection, constricted at septa, septa as thick as cell walls and anastomoses open, with short bridge, bridge thinner or as thick as hyphae, anastomoses closed, with long bridge, bridge bigger than hyphae. Very tip like other parts of the mantle.

Anatomical characters of emanating elements (Fig. $3 \mathrm{f}-\mathrm{h}$ ) Lacking are gelatinized hyphae, matrix, rhizomorphal nodia, simple septa, intrahyphal hyphae, crystals, brownish substances and secreted pigments; elbow-like protrusions not observed . Rhizomorphs undifferentiated, hyphae loosely interwoven and of uniform diameter (type A/B, Agerer and Rambold 2004-2015); hyphae smooth, cells 60-100 $\mu \mathrm{m}$ long, 2.8-5.2 $\mu \mathrm{m}$ diameter and cell walls $0.3 \mu \mathrm{m}$; ramification backwards-oriented or acute, one or two hyphal diameter below the septum or in considerable distance from the septum ramification and ramifications one side branch at septum; septa with clamps, backwards-oriented clamps not observed and septa as thick as hyphal walls; anastomoses are frequent, open with a short bridge, bridge slightly thicker than hyphae and cell walls of anastomoses as thick as remaining walls; surface of peripheral hyphae with few soil particles. Emanating hyphae straight to wavy, smooth, surface occasionally with few soil particles, cells (25) 65-115 $\mu \mathrm{m}$ long, 2.4-4.8 $\mu \mathrm{m}$ diameter, cell walls $0.3 \mu \mathrm{m}$ and distal ends of hyphae simple; ramification acute or approximately $90^{\circ}$, with one side branch at septum and one or two hyphal diameter below the septum; septa with clamps, constricted at septa, backwards-oriented 
Fig. 3 Arbutoid mycorrhiza of Cortinarius sp.-

Comarostaphylis arbutoides (sample KKM 298, subgenus Telamonia). a Habit of the telamonioid mycorrhiza with transparent, yellowish mantle, partly densely stringy mantle surface, and white rhizomorphs; $b a r=1 \mathrm{~mm}$. b Semi-thin section of telamonioid mycorrhiza with hyphal mantle $(H M)$, Hartig net $(H N)$ and intracellular hyphae $(i H) ;$ bar $=20 \mu \mathrm{m}$. c-h Plan view of different mantle layers and emanating elements of the telamonioid mycorrhiza; $b a r=10 \mu \mathrm{m}$. c Outer mantle layer with densely and irregularly arranged hyphae; hyphae with clamps and open anastomoses (asterisks). d Middle mantle layer with densely arranged hyphae, some hyphae in bundles; hyphae with open (asterisk) or closed anastomoses (arrowheads). e Inner mantle layer with densely arranged hyphae, hyphae in bundles, forming ring-like structures; hyphae with open (asterisks) or closed (arrowhead) anastomoses. f Emanating hyphae with open anastomoses,

backwards-oriented ramifications (single arrowheads) and backwards-oriented clamps (double arrowhead). $\mathbf{g}$ Rhizomorph with acute (single arrowhead) as well as backwardsoriented (double arrowheads) ramifications. h Hyphae of rhizomorphs with open anastomoses
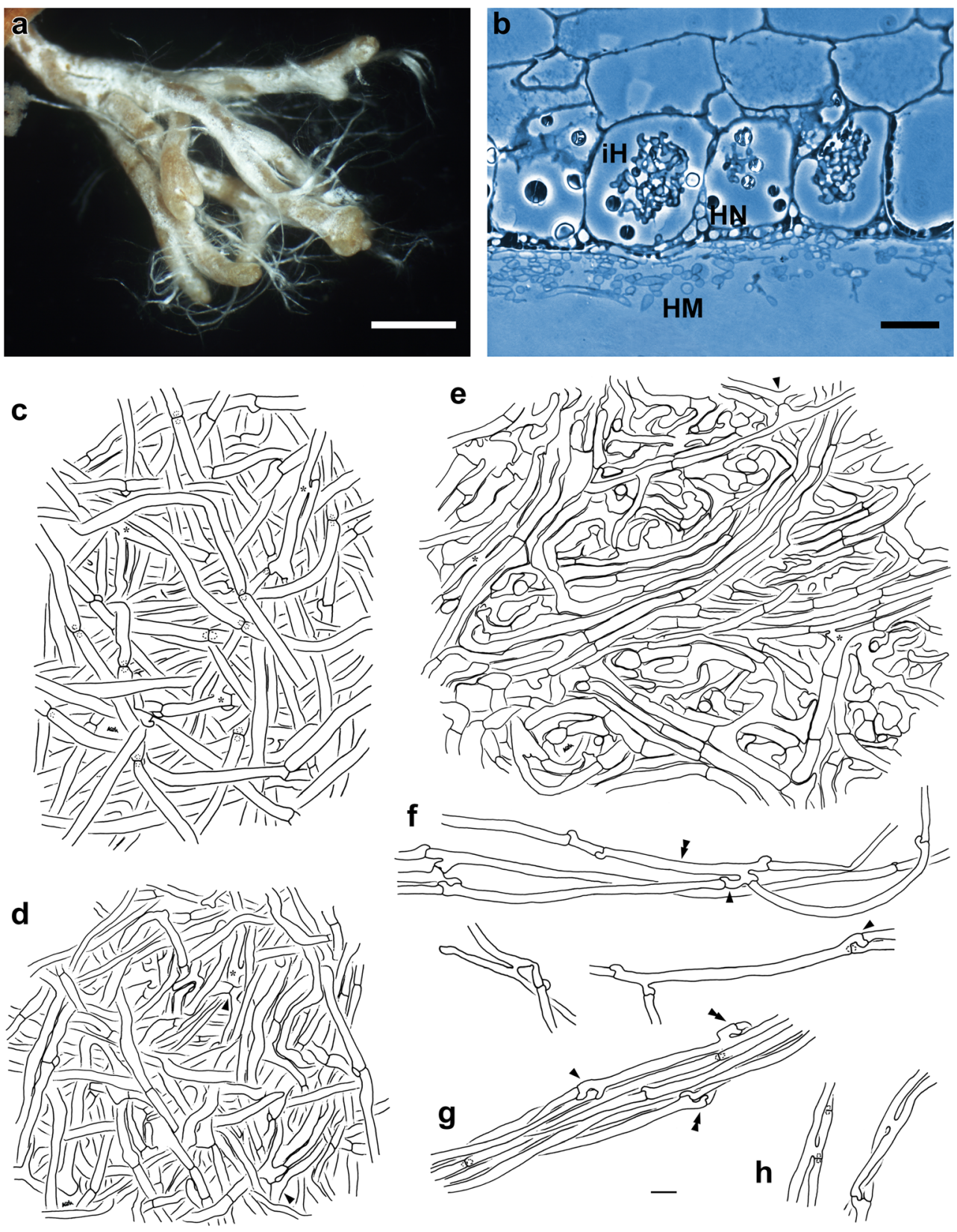

clamp observed only once, septa as thick as hyphal walls; anastomoses frequent, open with a short bridge, bridge thinner or as thick as hyphae and cell walls of anastomoses as thick as remaining walls. Cystidia not found.

Anatomical characters of longitudinal section (Fig. 3b) Mantle plectenchymatous, 10-22 $\mu \mathrm{m}$ thick. Mantle of very tip plectenchymatous, $10-17 \mu \mathrm{m}$ thick. Epidermal layer with intracellular hyphae and epidermal cells radially oval to eliptic; Hartig net around epidermal cells para-epidermal in one row and hyphal cells roundish to cylindrical. Tannin cells are lacking.
Colour reactions with different reagents (mantle preparations and emanating elements) Cotton blue: hyphae blue; toluidine blue: hyphae violet and cell content pink. No reaction was observed with: acetic acid, ethanol $70 \%, \mathrm{Fe}(\mathrm{II}) \mathrm{SO}_{4}$, guaiac, $\mathrm{KOH} 10 \%$, lactic acid, Lugol's solution, Melzer's reagent, $\mathrm{NH}_{4} \mathrm{OH}$ conc., sulpho-vanillin, $\mathrm{H}_{2} \mathrm{SO}_{4}$.

Reference specimen Costa Rica, province of San José, canton of Pérez Zeledón, at mountain Cerro de la Muerte, Estación Biológica de la Muerte (3100 m a.s.l; precipitation c. $2812 \mathrm{~mm} /$ year; lithosol (FAO)), in a secondary cloud forest with Q. costaricensis, soil core exc., myc. isol. Katja Kühdorf; 
KKM 298, 4 October 2011; mycorrhiza deposited by B. Münzenberger (ZALF Müncheberg, Germany).

\section{KKM 255, KKM 359 and KKM 388 (Dermocybe) + Com. arbutoides}

Morphological characters (Fig. 4a) Mycorrhizal systems irregularly pinnate to dichotomous, with 0-2 orders of ramification, systems solitary or in small numbers to abundant and dense, up to $9.9 \mathrm{~mm}$ long, slightly hydrophobic, of medium distance fringe exploration type. Main axes $0.2-0.6 \mathrm{~mm}$ diameter. Unramified ends bent or sinuous, not inflated, cylindric, up to $1.5(2.7) \mathrm{mm}$ long, $0.2-0.3 \mathrm{~mm}$ diameter; mantle ochre to yellowish brown, very tip yellowish, older parts dark orange and mycorrhizas not carbonising. Surface of unramified ends loosely stringy to loosely cottony, not smooth, between side branches and main axis sometimes fan-like cottony, slightly silvery by enclosed air, rapidly displaced by water when touched, then mantle generally transparent; epidermal cells visible through mantle. Rhizomorphs frequent, up to $0.11 \mathrm{~mm}$ diameter; flat in cross-section, emanating from all parts of the mycorrhiza, connection oblique, distal rhizomorphs connected over a long distance with mantle surface, growing into soil or organic layers, ochre to yellowish brown, repeatedly ramified into smaller filaments, with smooth margins. Cystidia lacking. Sclerotia not observed.

Anatomical characters of the mantle in plan views (Fig. 4c-e) Mantle lacks cells densely filled with oily droplets or brownish content, blue granules, needle-like contents,
Fig. 4 Arbutoid mycorrhiza of Cortinarius sp.-

Comarostaphylis arbutoides (samples KKM 255, KKM 359 and KKM 388; subgenus Dermocybe). a Habit of the dermocyboid mycorrhiza with transparent, ochre to yellowish brown mantle, loosely stringy mantle surface and ochre to yellowish brown rhizomorphs; bar $=0.5 \mathrm{~mm}$. b Semi-thin section of dermocyboid mycorrhiza with hyphal mantle $(H M)$, Hartig net $(H N)$ and intracellular hyphae $(i H)$; bar $=20 \mu \mathrm{m}$. c-h Plan view of different mantle layers and emanating elements of the dermocyboid mycorrhiza; bar $=10 \mu \mathrm{m}$. c Outer mantle layer with loosely and irregularly arranged hyphae, some hyphae in bundles and hyphae with clamps. d Middle mantle layer with densely arranged hyphae, some hyphae in bundles. e Inner mantle layer with densely arranged hyphae, hyphae in bundles, forming ring-like structures; hyphae with open anastomoses (asterisks). f Emanating hyphae with contact clamps and open anastomoses. $\mathrm{g}$ Rhizomorph with acute ramifications (arrowheads) h Hyphae of rhizomorphs with contact clamps and open anastomosis
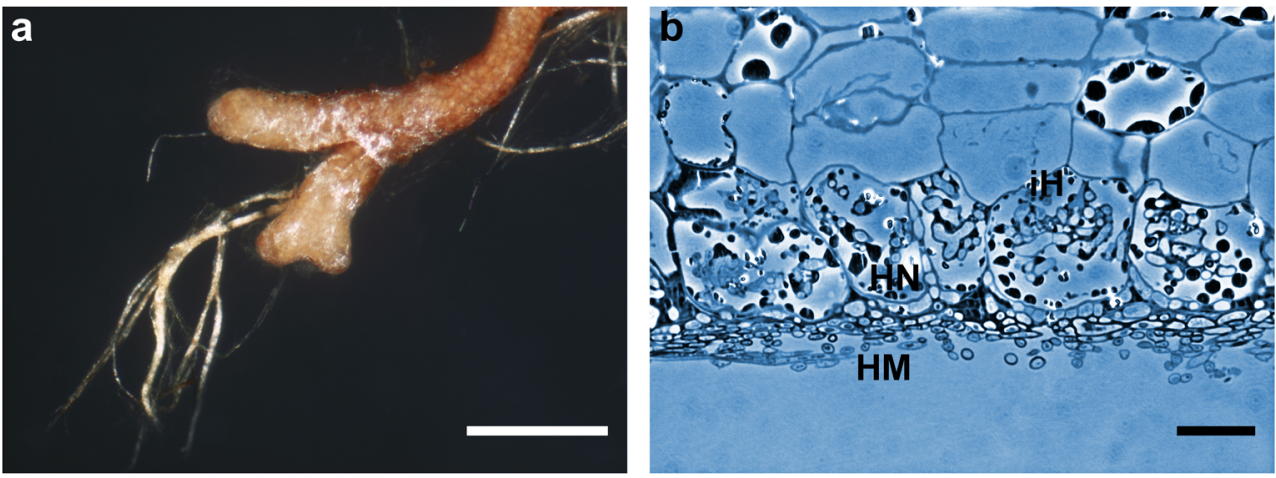

C

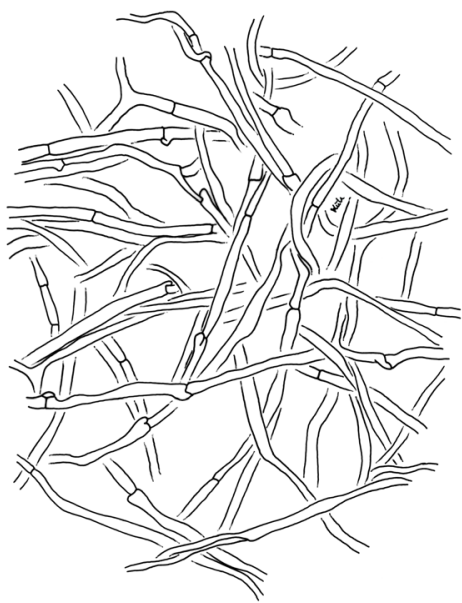

d

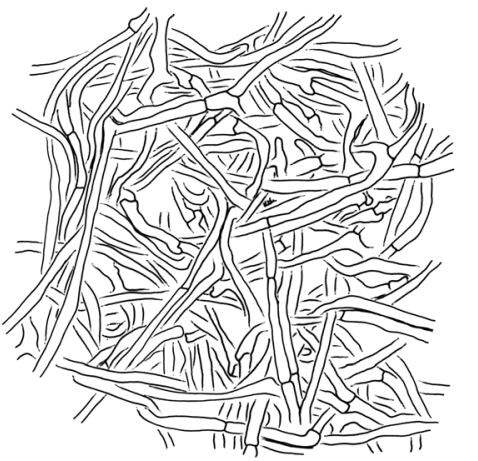

e
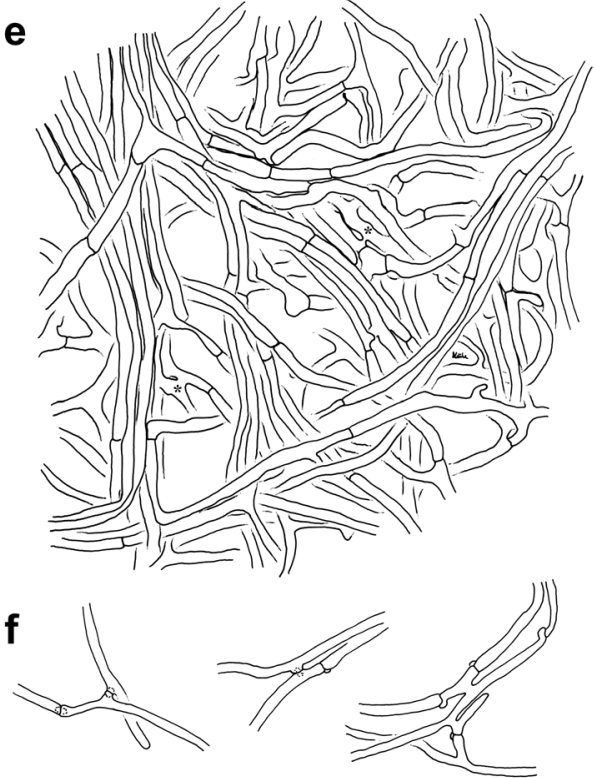

g

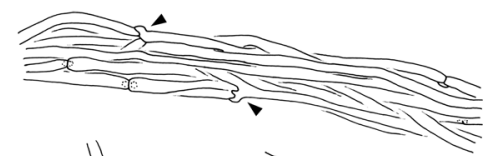

h

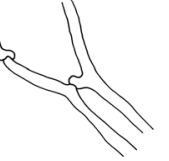


matrix, crystals and exudated pigments, as well as cystidia. Outer mantle layers loosely plectenchymatous, hyphae irregularly arranged, some hyphae in bundles, rarely ramified, without any special pattern (type B, Agerer 1991), colourless and with few soil particles; hyphae 25-90 $\mu \mathrm{m}$ long, 1.6$4.2 \mu \mathrm{m}$ in diameter and cells walls $0.3 \mu \mathrm{m}$ thick and hyphae with clamps, constricted at septa, septa as thick as cell walls. Middle mantle layers densely plectenchymatous, hyphae irregularly interwoven, some hyphae in bundles, occasionally ampullate at one side of septum, hyphae 15-50 $\mu \mathrm{m}$ long, 2.2$3.8 \mu \mathrm{m}$ in diameter, cell walls $0.3 \mu \mathrm{m}$ thick, smooth and colourless; hyphae with simple septa, rarely with clamps and constricted at septa, septa as thick as cell walls. Inner mantle layers densely plectenchymatous, hyphae in bundles, forming ring-like structures, occasionally ampullate at one side of septum, hyphae 17-200 $\mu \mathrm{m}$ long, 1.9-4.6 (5.3) $\mu \mathrm{m}$ in diameter, cell walls $0.3(0.4) \mu \mathrm{m}$ thick, smooth and colourless; hyphae with simple septa, constricted at septa and septa as thick as cell walls; anastomoses open, with short bridge, bridge thinner or as thick as hyphae. Very tip like other parts of the mantle.

\section{Anatomical characters of emanating elements (Fig. $4 \mathrm{f}-\mathrm{h}$ )} Lacking are gelatinized hyphae, matrix, rhizomorphal nodia, simple septa, intrahyphal hyphae, crystals, brownish substances and secreted pigments; elbow-like protrusions are not observed. Rhizomorphs undifferentiated, hyphae loosely interwoven and of uniform diameter (type A/B, Agerer and Rambold 2004-2015); hyphae smooth, cells 30-125 $\mu \mathrm{m}$ long, 2.8-4.3 $\mu \mathrm{m}$ diameter and cell walls $0.3 \mu \mathrm{m}$; ramification acute, one or two hyphal diameter below the septum and ramifications one side branch at septum; septa with clamps, constricted at septa, septa as thick as hyphal walls; anastomoses frequent, open or closed by a clamp (contact clamp), with a short bridge or bridge almost lacking, bridge as thick as hyphae, cell walls of anastomoses as thick as remaining walls. Emanating hyphae straight to wavy, smooth, surface occasionally with few soil particles, cells $40-110 \mu \mathrm{m}$ long, 2.1$3.8 \mu \mathrm{m}$ diameter, cell walls $0.3 \mu \mathrm{m}$ and distal ends of hyphae simple; ramification acute or approximately $90^{\circ}$, with one side branch at septum and one or two hyphal diameter below the septum; septa with clamps, constricted at septa, septa as thick as hyphal walls; anastomoses are frequent, open or closed by a clamp (contact clamp), with a short bridge or bridge almost lacking, bridge as thick as hyphae, cell walls of anastomoses as thick as remaining walls. Cystidia not found.

Anatomical characters of longitudinal section (Fig. 4b) Mantle plectenchymatous, 5-19 $\mu \mathrm{m}$ thick. Mantle of very tip plectenchymatous, 4-14 $\mu \mathrm{m}$ thick. Epidermal layer with intracellular hyphae, epidermal cells radially oval to eliptic; Hartig net around epidermal cells para-epidermal in one row and hyphal cells roundish to cylindrical. Tannin cells are lacking.
Colour reactions with different reagents (mantle preparations and emanating elements) Cotton blue: hyphae blue to patchy greenish; KOH $10 \%$ : rhizomorphs bright pink; $\mathrm{NH}_{4} \mathrm{OH}$ conc.: rhizomorphs bright pink after a few minutes; toluidine blue: hyphae violet, cell content pink. No reaction was observed with: acetic acid, ethanol $70 \%, \mathrm{Fe}(\mathrm{II}) \mathrm{SO}_{4}$, guaiac, lactic acid, Lugol's solution, Melzer's reagent, sulpho-vanillin, $\mathrm{H}_{2} \mathrm{SO}_{4}$.

Reference specimen Costa Rica, province of San José, canton of Pérez Zeledón, at mountain Cerro de la Muerte, Estación Biológica de la Muerte (3100 m a.s.1.; precipitation c. $2812 \mathrm{~mm} /$ year; lithosol (FAO)), in a secondary cloud forest with $Q$. costaricensis, soil core exc., myc. isol. Katja Kühdorf; KKM 255, 4 October 2011 and mycorrhiza deposited by B. Münzenberger (ZALF Müncheberg, Germany). Further material studied Costa Rica, province of San José, canton of Pérez Zeledón, at mountain Cerro de la Muerte, Reserva Forestal Los Santos (3300 m a.s.1.; precipitation c. $2812 \mathrm{~mm} /$ year; inceptisol (USDA)), in a secondary cloud forest with $Q$. costaricensis, soil core exc., myc. isol. Katja Kühdorf; KKM 359 and KKM 388, 18 October 2011; mycorrhiza deposited by B. Münzenberger (ZALF Müncheberg, Germany).

\section{KKM 149 (Dermocybe) + Com. arbutoides}

Morphological characters (Fig. 5a) Mycorrhizal systems irregularly pinnate to dichotomous, with $0-2$ orders of ramification, systems abundant and dense, up to $11.3 \mathrm{~mm}$ long, slightly hydrophobic and of medium distance fringe exploration type. Main axes $0.3-0.5 \mathrm{~mm}$ diameter. Unramified ends sinuous to tortuous, not inflated, cylindric, up to $1.6(2.5) \mathrm{mm}$ long, $0.3 \mathrm{~mm}$ diameter; mantle brown, very tip brownish to greyish, older parts dark brown and mycorrhizas not carbonising. Surface of unramified ends loosely stringy to loosely cottony, not smooth, between side branches and main axis sometimes fan-like cottony, slightly silvery by enclosed air, rapidly displaced by water when touched, then mantle generally transparent and epidermal cells visible through mantle. Rhizomorphs frequent, up to $0.13 \mathrm{~mm}$ diameter, flat in cross-section, emanating from all parts of the mycorrhiza, connection oblique, distal rhizomorphs connected over a long distance with mantle surface, growing into soil or organic layers, ochre to reddish brown, repeatedly ramified into smaller filaments, with smooth margins. Cystidia lacking. Sclerotia not observed.

Anatomical characters of the mantle in plan views (Fig. $5 \mathrm{c}-$ e) Mantle lacks cells densely filled with oily droplets or brownish content, blue granules, needle-like contents, matrix, crystals and exudated pigments, as well as cystidia. Outer mantle layers loosely plectenchymatous, hyphae irregularly arranged, rarely 
Fig. 5 Arbutoid mycorrhiza of Cortinarius sp.-

Comarostaphylis arbutoides (sample KKM 149, subgenus Dermocybe). a Habit of the dermocyboid mycorrhiza with transparent, brown-coloured mantle, loosely stringy mantle surface and ochre to reddish brown rhizomorphs $=b a r$ $0.5 \mathrm{~mm}$. b Semi-thin section of dermocyboid mycorrhiza with hyphal mantle (HM), Hartig net $(H N)$ and intracellular hyphae (iH); bar $=20 \mu \mathrm{m}$. c-h Plan view of different mantle layers and emanating elements of the dermocyboid mycorrhiza; bar $=10 \mu \mathrm{m}$. c Outer mantle layer with loosely and irregularly arranged hyphae; hyphae with clamps. d Middle mantle layer with densely arranged hyphae, some hyphae in bundles. e Inner mantle layer with densely arranged hyphae, hyphae in bundles, forming ring-like structures; hyphae with open anastomoses (asterisks). f Emanating hyphae with open anastomoses (single arrowheads), backwards-oriented ramification and with contact clamps. $\mathbf{g}$ Rhizomorph with contact clamp (asterisk) and acute ramification (arrowhead). h Hyphae of rhizomorphs with acute ramification, open anastomoses and contact clamps
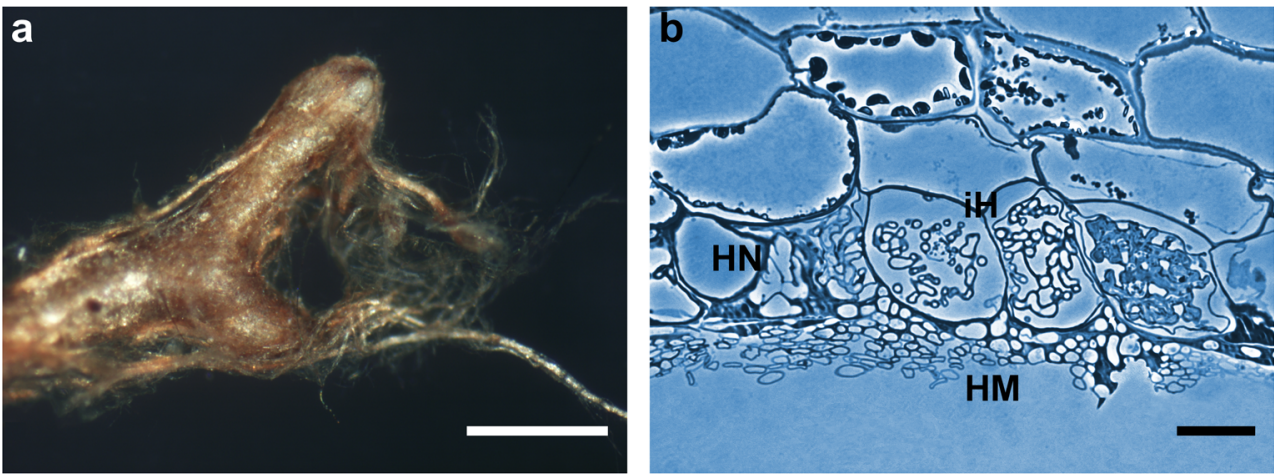

c

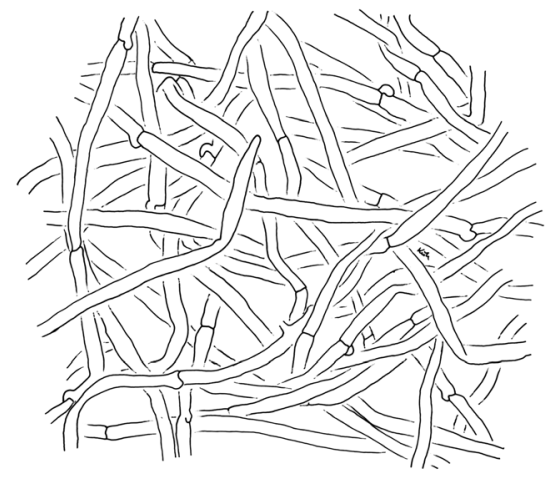

d
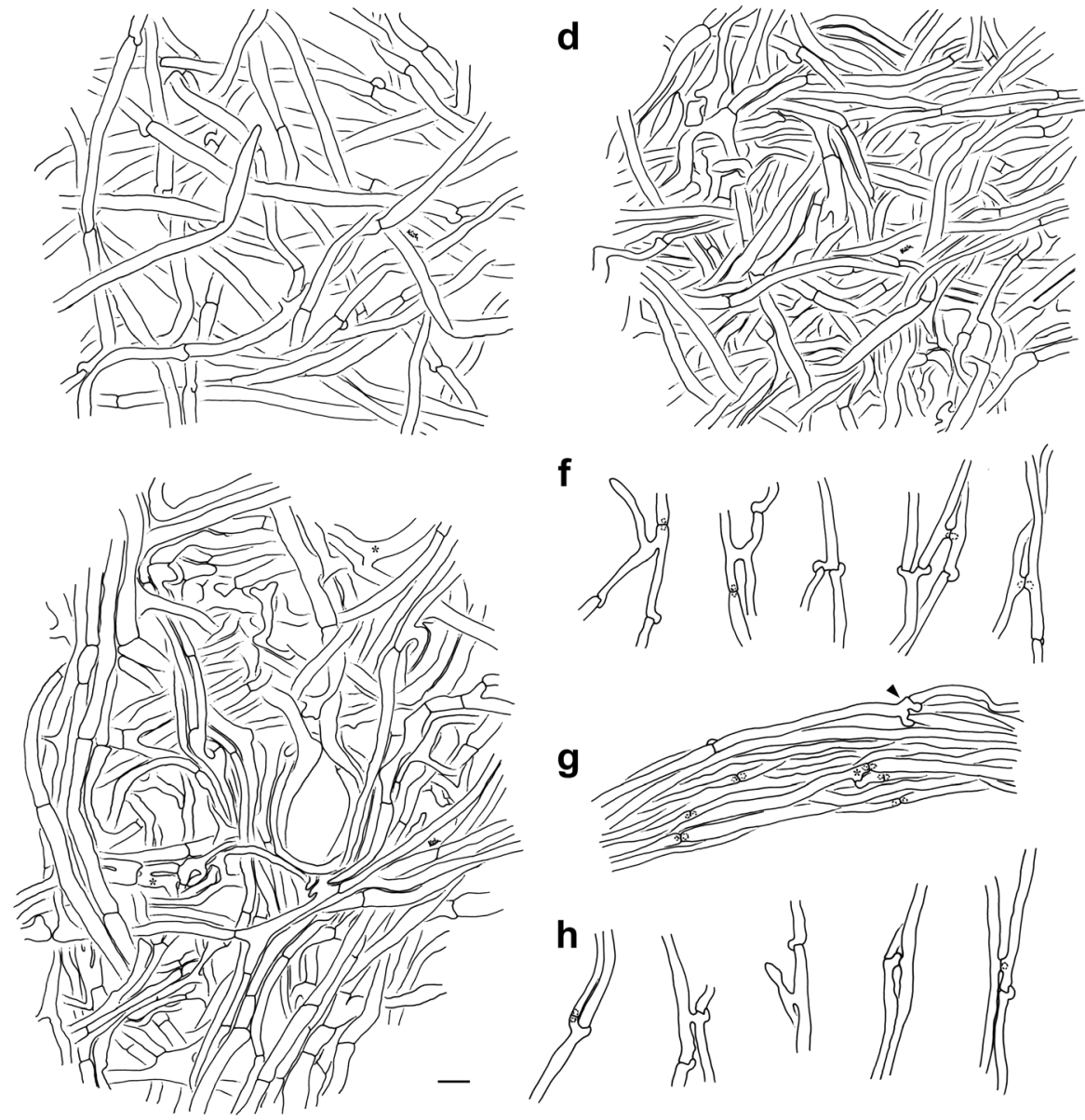

f
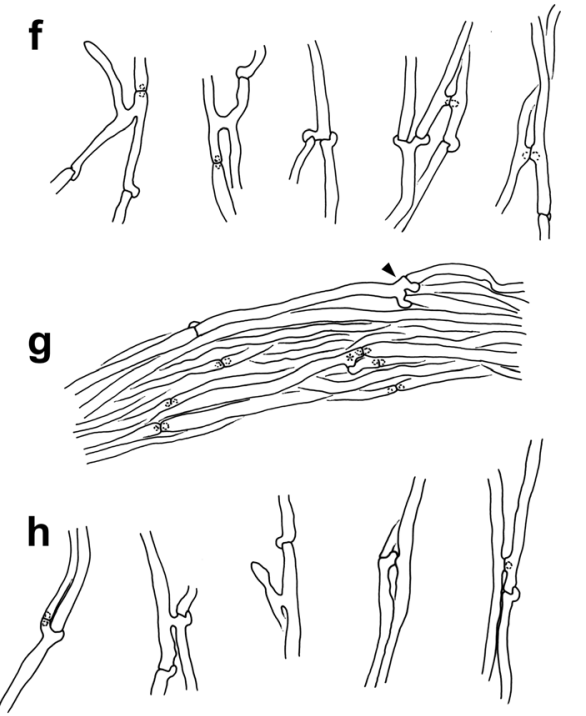

ramified, without any special pattern (type B, Agerer 1991), colour yellowish to colourless and with few soil particles; hyphae 20-59 (100) $\mu \mathrm{m}$ long, 3.5-4.7 $\mu \mathrm{m}$ in diameter, cells walls 0.3 (0.4) $\mu \mathrm{m}$ thick; hyphae with clamps, constricted at septa and septa as thick as cell walls. Middle mantle layers densely plectenchymatous, some hyphae in bundles or irregularly interwoven, sometimes ampullate at one side of septum, hyphae 20 $110 \mu \mathrm{m}$ long, 2.8-5.8 $\mu \mathrm{m}$ in diameter, cell walls $0.3 \mu \mathrm{m}$ thick, smooth and colourless; hyphae with simple septa, rarely with clamps, constricted at septa and septa as thick as cell walls. Inner mantle layers are densely plectenchymatous, hyphae in bundles, forming ring-like structures, sometimes ampullate at one side of septum, hyphae uneven in diameter, hyphae 30 $200 \mu \mathrm{m}$ long, $1.3-5.1 \mu \mathrm{m}$ in diameter, cell walls $0.3-0.4 \mu \mathrm{m}$ thick, smooth and colourless; hyphae with simple septa, constricted at septa and septa as thick as cell walls; anastomoses open with short bridge, bridge thinner or as thick as hyphae. Very tip is like other parts of the mantle.

Anatomical characters of emanating elements (Fig. $5 \mathrm{f}-\mathrm{h}$ ) Lacking are gelatinized hyphae, matrix, rhizomorphal nodia, simple septa, intrahyphal hyphae, crystals, brownish substances and secreted pigments; elbow-like protrusions not observed. Rhizomorphs undifferentiated, hyphae loosely 
interwoven and of uniform diameter (type A/B, Agerer and Rambold 2004-2015); hyphae smooth, cells 20-90 $\mu \mathrm{m}$ long, 2.4-3.8 $\mu \mathrm{m}$ diameter, cell walls $0.3 \mu \mathrm{m}$; ramification acute, one or two hyphal diameter below the septum and ramifications one side branch at septum; septa with clamps, constricted at septa and septa as thick as hyphal walls; anastomoses are frequent, closed by a clamp or rarely open, with a short bridge or bridge almost lacking, bridge as thick as hyphae and cell walls of anastomoses as thick as remaining walls. Emanating hyphae straight to wavy, smooth, surface occasionally with few soil particles, cells 20-95 $\mu \mathrm{m}$ long, 2.1-3.8 (4.7) $\mu \mathrm{m}$ diameter, cell walls $0.3 \mu \mathrm{m}$, and distal ends of hyphae simple; ramification acute or approximately $90^{\circ}$, with one side branch at septum, one or two hyphal diameter below the septum, backwards-oriented ramification observed only once; septa with clamps, constricted at septa and septa as thick as hyphal walls; anastomoses frequent, closed by a clamp (contact clamp) or rarely open, with a short bridge or bridge almost lacking, bridge as thick as hyphae and cell walls of anastomoses as thick as remaining walls. Cystidia not found.

Anatomical characters of longitudinal section (Fig. 5b) Mantle plectenchymatous, 4-16 $\mu \mathrm{m}$ thick. Mantle of very tip plectenchymatous, 4-11 $\mu \mathrm{m}$ thick. Epidermal layer with intracellular hyphae and epidermal cells radially oval to eliptic; Hartig net around epidermal cells para-epidermal in one row and hyphal cells roundish to cylindrical. Tannin cells are lacking.

Colour reactions with different reagents (mantle preparations and emanating elements) Cotton blue: hyphae blue to patchy greenish; KOH $10 \%$ : rhizomorphs bright pink; $\mathrm{NH}_{4} \mathrm{OH}$ conc.: rhizomorphs bright pink after a few minutes; toluidine blue: hyphae violet and cell content pink. No reaction was observed with: acetic acid, ethanol $70 \%, \mathrm{Fe}(\mathrm{II}) \mathrm{SO}_{4}$, guaiac, lactic acid, Lugol's solution, Melzer's reagent, sulphovanillin, $\mathrm{H}_{2} \mathrm{SO}_{4}$.

Reference specimen Costa Rica, province of San José, canton of Pérez Zeledón, at mountain Cerro de la Muerte, Reserva Forestal Los Santos (3300 m a.s.1.; precipitation c. $2812 \mathrm{~mm} /$ year; inceptisol (USDA)), in a secondary cloud forest with Q. costaricensis, soil core exc., myc. isol. Katja Kühdorf; KKM 149, 12 October 2010; mycorrhiza deposited by B. Münzenberger (ZALF Müncheberg, Germany).

\section{Discussion}

Despite the efforts in investigating the biodiversity of Costa Rican Cortinarii, only Ammirati et al. (2007) supplied genetic data for their reported species. This makes it difficult to address mycorrhizal findings to already known species. With one exception, none of the cortinarioid mycorrhizas, found in Costa Rica, can be determined to species level.

However, due to sequence identity of $100 \%$, the mycorrhizal sample KKM 144 can most probably be assigned to C. comarostaphylii. This species occurs in the Costa Rican páramo (Halling and Mueller 1999) and, according to Ammirati et al. (2007), C. comarostaphylii seems to be restricted to the Ericaceae Com. arbutoides. This plant was also confirmed genetically as host plant for the mycorrhiza KKM 144. Due to strict host specificity of many Cortinarius species (e.g. Brandrud 1996; Liimatainen 2013), identification with the European species C. leucophanes (Fig. 1) is excluded, since this species is associated with conifers (Ammirati et al. 2007).

Based on phylogenetic analyses, the sample KKM 132 is placed in the subgenus Phlegmacium, but fitted laboriously into this subgenus during processing. Also, the databases NCBI and UNITE reached comparatively low identity values, which confirms the insufficient sequence data quantity of Costa Rican Cortinarii. However, beside Cortinarius glaucopus, Halling and Mueller (1999) mention another phlegmacioid Cortinarii from the Costa Rican páramo. Since no sequence data is available, it remains unclear, whether or not this unidentified Phlegmacium species correspond to our mycorrhizal sample KKM 132.

\section{Mycorrhiza assigned to subgenus Phlegmacium}

The mycorrhiza KKM 132 strongly differs in morphology from phlegmacioid ectomycorrhizas (ECMs) hitherto described in DEEMY (Cortinarius alnobetulae (Wiedmer and Senn-Irlet 1999a), Cortinarius calochrous ssp. coniferarum (Kernaghan 2001), Cortinarius kuehneri (Wiedmer and Senn-Irlet 1999b), C. odorifer (Uhl 1988; Egli 1992), as well as Cortinarius variecolor (Agerer 1969, 1988)). All these ECMs offer a silvery surface, whereas our Phlegmacium sample from Costa Rica lacks this feature. However, amongst this feature and its dense stringy surface, the ochre to yellowish colour, as well as the lack of sclerotia, KKM 132 resembles the Cortinariaceae "Nothofagirhiza reticulosa" from Chile (Palfner 2001; Agerer and Rambold 2004-2015).

Anatomically, KKM 132 resembles "N. reticulosa" in showing similar plectenchymatous mantle structures. However, in contrast to KKM 132, "N. reticulosa" possess anastomoses in the outer mantle layer, a rough hyphal surface in the outer mantle layer as well as in the emanating elements, and simple septa as well as intrahyphal hyphae in the emanating hyphae.

The phlegmacioid mycorrhiza of KKM 132 shows no reaction with $\mathrm{KOH}$, an attribute in common with $C$. alnobetulae and " $N$. reticulosa". However, both samples differ from KKM 132 in lacking reaction with cotton blue and toluidine blue, and a positive reaction with sulpho-vanillin, respectively. The likewise absent reaction with $\mathrm{NH}_{4} \mathrm{OH}$ of KKM 132 was not investigated in the other mycorrhizal samples of Phlegmacium. 


\section{Mycorrhiza assigned to subgenus Telamonia}

In DEEMY and literature, the following ECMs of the subgenus Telamonia are described as follows: Cortinarius armillatus (Cuvelier 1990; Cuvelier and Agerer 1991), Cortinarius atropusillus (Wiedmer and Senn-Irlet 1999c), Cortinarius badiovestitus (Wiedmer and Senn-Irlet 1999d), Cortinarius bibulus (Wiedmer and Senn-Irlet 2001a), Cortinarius bulliardii (Raidl et al. 2006), Cortinarius cinnabarinus (Ceruti et al. 1988; Brand 1991, 1992), Cortinarius helvelloides (Wiedmer and Senn-Irlet 2001b), Cortinarius hinnuleus (Kovács et al. 2002), Cortinarius malachius (Uhl 1988), Cortinarius obtusus (Agerer 1987a; Gronbach 1988; Gronbach and Agerer 1988) and Cortinarius saturninus (Seress et al. 2012). Here, C. obtusus resembles our telamonioid mycorrhiza KKM 298 with the silvery surface, white rhizomorphs with smooth margins, and the medium distance fringe exploration type.

Anatomically, the KKM 298 differs clearly from the 11 Cortinarius subgenus Telamonia ECMs. C. badiovestitus, C. bibulous, C. hinnuleus and C. obtusus have contact clamps in their emanating elements, whereas KKM 298 possesses no contact clamps at all. The anastomoses of $C$. cinnabarinus are not only open with a short bridge but are also closed by a clamp with a long bridge. Moreover, together with C. bulliardii and C. malachius and C. cinnabarinus show differentiated rhizomorphs of type $\mathrm{D}$ or $\mathrm{C}$, whereas these of KKM 298 are assigned to type A/B. The mycorrhiza of C. saturninus is the only one which offers a matrix in the mantle layers as well as in the rhizomorphs. Together with C. armillatus, both systems feature not only clamps but also secondary septa in the emanating elements which were, in contrast, not observed in KKM 298. None of the Cortinarius species possess open anastomoses in all three mantle layers, whereby, in the case of $C$. cinnabarinus, $C$. hinnuleus and C. saturninus no middle mantle layer was described. Secondly, a distinctly ring-like arrangement of the inner mantle layer, as was also shown for KKM 298, was not described in any of the 11 telamonioid Cortinarius ECMs.

For chemical reactions, only $\mathrm{KOH}$ was tested in all described Cortinarius subgenus Telamonia ECMs. Here, no reaction was observed for KKM 298, as well as for most of the other telamonioid species. Exceptions are C. bulliardii, C. cinnabarinus and C. malachius which show violet pink, red-violet colour reactions or dissolving incrustations. A likewise negative reaction with $\mathrm{NH}_{4} \mathrm{OH}$, as shown for $\mathrm{KKM} 298$, cannot be conformed since the other telamoinioid systems were not tested. For $C$. armillatus, no information on chemical reactions is given at all.

\section{Mycorrhizas assigned to subgenus Dermocybe}

Currently, nine ECMs of the subgenus Dermocybe are described in DEEMY: Dermocybe cinnamomea (Agerer 1987b; Agerer and Gronbach 1987; Gronbach 1988; Berg 1989; Weiss 1988), Dermocybe cinnamomeolutea (Waller and Agerer 1993), Dermocybe crocea (Uhl and Agerer 1987, 1988; Uhl 1988), Dermocybe holoxantha (Uhl 1988; Agerer 1995), Dermocybe huronensis (Kuss et al. 2004), Dermocybe palustris (Uhl and Agerer 1987; Agerer 1995), Dermocybe phoenicea (Cuvelier 1990), Dermocybe sanguinea (Agerer 1987b, c), as well as Dermocybe semisanguinea (Uhl 1988; Agerer and Uhl 1989; Agerer 1995). Due to the ochre to yellowish brown-coloured mantle and rhizomorphs, the mycorrhizal systems of KKM 255, KKM 359 and KKM 388 ("Dermocybe I") are similar to D. cinnamomeolutea. In contrast, the system of KKM 149 ("Dermocybe II") shows a brown to dark brown mantle with a reddish tint, as is also common with $D$. phoenicea. However, both described mycorrhizas show a distinctly transparent mantle clearly distinguishing them from the other Dermocybe species described in DEEMY so far.

Anatomically, the mycorrhizas of "Dermocybe I" and "Dermocybe II" do not differ much. Both types show a plectenchymatous mantle throughout undifferentiated rhizomorphs, infrequently with smooth margins (types A or B) and both form short anastomoses with contact clamps. These features are typical for Dermocybe species (Agerer 1995). According to DEEMY, our samples herein resemble D. cinnamomeolutea, D. holoxantha and D. huronensis. Nevertheless, these three species also show clear differences. Hyphae of emanating elements (D. huronensis), as well as of the outer mantle layer (D. cinnamomeolutea) possess a rough surface. D. cinnamomeolutea and D. holoxantha have a matrix in the middle and inner mantle layers and, furthermore, none of these three species show a ring-like inner mantle layer as occurs in both, "Dermocybe I" and "Dermocybe II". Anastomoses open or closed by a clamp, are very common in the emanating elements, whereas in "Dermocybe II", open anastomoses are less frequently observed than in "Dermocybe I". Within the described Dermocybe ECM only, D. phoenicea also feature these two types of anastomoses.

The rhizomorphs of "Dermocybe I" and "Dermocybe II" show a bright pink colour reaction with $\mathrm{KOH}$, as well as with $\mathrm{NH}_{4} \mathrm{OH}$. A colour reaction with $\mathrm{NH}_{4} \mathrm{OH}$ was only tested in D. cinnamomea, where no reaction was observed. A reaction with $\mathrm{KOH}$ was investigated in seven of the nine Dermocybe species, where again, D. cinnamomea, as well as D. palustris showed a reaction, but which only affected the hyphal content or the mantle, respectively.

According to Ammirati et al. (2007), Costa Rica has a limited number of confirmed host plants for ectomycorrhizal fungi, such as Quercus sp., Com. arbutoides and Alnus acuminate. Even though oak species have an extensive distribution and are the most common ectomycorrhizal host plant 
for Cortinarius, they only occur in small numbers. Additionally, some Cortinarius species have very special habitat preferences (Liimatainen 2013) and, amongst topographical factors, often only exist in small, geographically isolated populations (Frøslev et al. 2005). Beside insufficient recorded biodiversity, this explains why the Cortinarius findings in this study primarily differ from Ammirati et al. (2007), and why species of, e.g. subgenus Dermocybe have not been reported yet for Costa Rica. Moreover, in contrast to Ammirati et al. (2007), who described Costa Rican Cortinarii sporocarps exclusively found in June, we found no fruit bodies at all. This suggests that sampling in October, within the rainy season, is suitable for mycorrhizal investigations but not for Cortinarius fruit bodies in this area.

Acknowledgments We are grateful to Monika Roth for excellent technical assistance. We would also like to thank Mary T. Lavin-Zimmer from the GFZ German Research Centre for Geosciences for English corrections and Federico Valverde as well as Silvia Lobo Cabezas for their assistance in the cloud forests of Costa Rica. The authors are indebted to the German Research Foundation (DFG) for funding this project (Mu 1035/15-1).

Open Access This article is distributed under the terms of the Creative Commons Attribution 4.0 International License (http:// creativecommons.org/licenses/by/4.0/), which permits unrestricted use, distribution, and reproduction in any medium, provided you give appropriate credit to the original author(s) and the source, provide a link to the Creative Commons license, and indicate if changes were made.

\section{References}

Agerer R (1969) Cortinarius variecolor. In: Agerer R (ed) Colour atlas of ectomycorrhizae, plate 24. Einhorn-Verlag, Schwäbisch Gmünd

Agerer R (1987-2012) Colour atlas of ectomycorrhizae. 1st-15th delivery, Einhorn, Schwäbisch Gmünd

Agerer R (1987b) Studies on ectomycorrhizae X. Mycorrhizae formed by Cortinarius obtusus and C. venetus on spruce. Mycologia 79:524539

Agerer R (1987c) Studies on ectomycorrhizae V. Mycorrhizae formed by Dermocybe cinnamomea and D. sanguinea on spruce. Nova Hedwigia 44:69-89

Agerer R (1987d) Dermocybe sanguinea. In: Agerer R (ed) Colour atlas of ectomycorrhizae, plate 8. Einhorn-Verlag, Schwäbisch Gmünd

Agerer R (1988) Studies on ectomycorrhizae XIV. Mycorrhizae formed by Cortinarius hercynicus and C. variecolor on Picea abies. Can J Bot 66:2068-2078

Agerer R (1991) Characterization of ectomycorrhiza. In: Norris JR, Read DJ, Varma AK (eds) Methods in microbiology, vol 23, Techniques for the study of mycorrhiza. Academic, London, pp 25-74

Agerer R (1995) Anatomical characteristics of identified ectomycorrhizas: an attempt towards a natural classification. In: Varma A, Hock B (eds) Mycorrhiza: structure, function, molecular biology and biotechnology. Springer, Berlin, pp 685-734

Agerer R, Gronbach E (1987) Dermocybe cinnamomea. In: Agerer R (ed) Colour atlas of ectomycorrhizae, plate 7. Einhorn-Verlag, Schwäbisch Gmünd

Agerer R, Rambold G (2004-2015) DEEMY — an information system for characterization and determination of ectomycorrhizae. München, Germany. http://www.deemy.de. Accessed 21 October 2015
Agerer R, Uhl M (1989) Dermocybe semisanguinea. In: Agerer R (ed) Colour atlas of ectomycorrhizae, plate 25. Einhorn-Verlag, Schwäbisch Gmünd

Ammirati J, Garnica S, Halling RE, Mata M, Mueller GM, Carranca J (2007) New Cortinarius species associated with Quercus and Comarostaphylis in Costa Rica. Can J Bot 85:794-812

Berg B (1989) Charakterisierung und Vergleich von Ektomykorrhizen gekalkter Fichtenbestände. Dissertation, University of Munich

Bidartondo MI, Bruns TD (2001) Extreme specificity in epiparasitic Monotropoideae (Ericaceae): widespread phylogenetic and geographical structure. Mol Ecol 10:2285-2295

Brand F (1991) Ektomykorrhizen an Fagus sylvatica. Charakterisierung und Identifizierung, ökologische Kennzeichnung und unsterile Kultivierung. Libri Bot 2:1-229

Brand F (1992) Cortinarius cinnabarinus. In: Agerer R (ed) Colour atlas of ectomycorrhizae, plate 68. Einhorn-Verlag, Schwäbisch Gmünd

Brandrud TE (1996) Cortinarius, subgenus Phlegmacium, section Phlegmacium in Europe. A study of character variation and ecology including a numerical analysis of the $C$. argutus complex. Mycol Res 100:471-485

Ceruti A, Benvenuti R, Luppi Mosca AM (1988) Micorrize di Fagus sylvatica con specie di Lactarius, Russula, Laccaria e Cortinarius. Allionia 28:125-134

Cuvelier J-J (1990) Caractérisation des ectomycorhizes de Betula pendula (I): Cortinarius armillatus, Dermocybe phoenicea et Amanita muscaria. Belg J Bot 123:73-91

Cuvelier J-J, Agerer R (1991) Cortinarius armillatus. In: Agerer R (ed) Colour atlas of ectomycorrhizae, plate 52. Einhorn-Verlag, Schwäbisch Gmünd

Dima B, Liimatainen K, Niskanen T, Kytövuori I, Bojantchev D (2014) Two new species of Cortinarius, subgenus Telamonia, sections Colymbadini and Uracei, from Europe. Mycol Prog 13:867-879

Egli S (1992) Der Anisklumpfuß, Cortinarius odorifer Britz.: Ökologie, Biologie und Ektomykorrhiza. Mitteilungen der Eidgenössischen Forschungsanstalt für Wald. Schnee Landschaft 67:317-412

Frøslev TG, Matheny PB, Hibbett DS (2005) Lower level relationships in the mushroom genus Cortinarius (Basidiomycota, Agaricales): a comparison of RPB1, RPB2, and ITS phylogenies. Mol Phylogenet Evol 37:602-618

Frøslev TG, Jeppesen TS, Læssøe T, Kjøller R (2007) Molecular phylogenetics and delimitation of species in Cortinarius section Calochroi (Basidiomycota, Agaricales) in Europe. Mol Phylogenet Evol 44:217-227

Gardes M, Bruns TD (1993) ITS primers with enhanced specificity for basidiomycetes - application to the identification of mycorrhizae and rusts. Mol Ecol 2:113-118

Garnica S, Weiß M, Oertel B, Oberwinkler F (2003) Phylogenetic relationships of European Phlegmacium species (Cortinarius, Agaricales). Mycologia 95:1155-1170

Garnica S, Weiß M, Oertel B, Oberwinkler F (2005) A framework for a phylogenetic classification in the genus Cortinarius (Basidiomycota, Agaricales) derived from morphological and molecular data. Can J Bot 83:1457-1477

Garnica S, Weiß M, Oertel B, Ammirati J, Oberwinkler F (2009) Phylogenetic relationships in Cortinarius, section Calochroi, inferred from nuclear DNA sequences. BMC Evol Biol 9:1. doi:10. 1186/1471-2148-9-1

Garnica S, Spahn P, Oertel B, Ammirati J, Oberwinkler F (2011) Tracking the evolutionary history of Cortinarius species in section Calochroi, with transoceanic disjunct distributions. BMC Evol Biol 11:213. doi:10.1186/1471-2148-11-213

Gronbach E (1988) Charakterisierung und Identifizierung von Ektomykorrhizen in einem Fichtenbestand mit Untersuchungen zur Merkmalsvariabilität in sauer beregneten Flächen. Bibl Mycol $125: 1-217$ 
Gronbach E, Agerer R (1988) Cortinarius obtusus. In: Agerer R (ed) Colour atlas of ectomycorrhizae, plate 12. Einhorn-Verlag, Schwäbisch Gmünd

Halling RE, Mueller GM (1999) Macrofungi of Costa Rica. http://www. nybg.org/bsci/res/hall/. Accessed 21 Jan 2016

Halling RE, Mueller GM (2005) Common mushrooms of the Talamanca mountains, Costa Rica. New York Botanical Garden Press, Bronx

Katoh K, Misawa K, Kuma K, Miyata T (2002) MAFFT: a novel method for rapid multiple sequence alignment based on fast Fourier transform. Nucleic Acids Res 30:3059-3066

Kernaghan G (2001) Ectomycorrhizal fungi at tree line in the Canadian Rockies II. Identification of ectomycorhizae by anatomy and PCR. Mycorrhiza 10:217-229

Kõljalg U, Larsson K-H, Abarenkov K, Nilsson RH, Alexander IJ, Eberhardt U, Erland S, Høiland K, Kjøller R, Larsson E, Pennanen T, Sen R, Taylor AFS, Tedersoo L, Vrålstad T, Ursing BM (2005) UNITE: a database providing web-based methods for the molecular identification of ectomycorrhizal fungi. New Phytol 166:1063-1068

Kovács GM, Jakucs E, Diéz J, Manjón JL, Esteve-Raventós F (2002) Cortinarius hinnuleus Fr. + Betula celtiberica Rothm. \& Vasc. In: Agerer R, Danielson RM, Egli S, Ingleby K, Luoma D, Treu R (eds) Descriptions of ectomycorrhizae, vol 5. Einhorn, Schwäbisch Gmünd, pp 7-11

Kühdorf K, Münzenberger B, Begerow D, Karasch-Wittmann C, GómezLaurito J, Hüttl RF (2014) Sebacina sp. is a mycorrhizal partner of Comarostaphylis arbutoides (Ericaceae). Mycol Prog 13:733-744

Kühdorf K, Münzenberger B, Begerow D, Gómez-Laurito J, Hüttl RF (2015) Leotia cf. lubrica forms arbutoid mycorrhiza with Comarostaphylis arbutoides (Ericaceae). Mycorrhiza 25:109-120

Kuss P, Raidl S, Beenken L (2004) Cortinarius huronensis Ammirati \& Smith var. huronensis + Pinus rotundata Link. In: Agerer R, Danielson RM, Egli S, Ingleby K, Luoma D, Treu R (eds) Descriptions of ectomycorrhizae, vol 7/8. Einhorn, Schwäbisch Gmünd, pp 21-27

Liimatainen K (2013) Towards a better understanding of the systematics and diversity of Cortinarius, with an emphasis on species growing in boreal and temperate zones of Europe and North America. Dissertation, University of Helsinki

Liimatainen K, Niskanen T, Ammirati JF, Kytövuori I, Dima B (2015) Cortinarius, subgenus Telamonia, section Disjungendi, cryptic species in North America and Europe. Mycol Prog 14:1016. doi:10. 1007/s11557-014-1016-9

Molina R, Trappe JM (1982) Lack of mycorrhizal specificity by the ericaceous hosts Arbutus menziesii and Arctostaphylos uva-ursi. New Phytol 90:495-509

Moncalvo J-M, Lutzoni FM, Rehner SA, Johnson J, Vilgalys R (2000) Phylogenetic relationships of agaric fungi based on nuclear large subunit ribosomal DNA sequences. Syst Biol 49:278-305

Mueller GM, Halling RE, Carranza J, Mata M, Schmit JP (2006) Saprotrophic and ectomycorrhizal macrofungi of Costa Rican oak forests. In: Kappelle M (ed) Ecology and conservation of neotropical montane oak forests. Springer, Berlin, Heidelberg, pp 55-68

Münzenberger B, Bubner B, Wöllecke J, Sieber TN, Bauer R, Fladung M, Hüttl RF (2009) The ectomycorrhizal morphotype Pinirhiza sclerotia is formed by Acephala macrosclerotiorum sp. nov., a close relative of Phialocephala fortinii. Mycorrhiza 19:481-492

Niskanen T, Kytövuori I, Liimatainen K (2011) Cortinarius sect. Armillati in northern Europe. Mycologia 103:1080-1101

Niskanen T, Kytövuori I, Liimatainen K, Lindström H (2013a) The species of Cortinarius, section Bovini, associated with conifers in northern Europe. Mycologia 105:977-993

Niskanen T, Liimatainen K, Ammirati JF, Hughes K (2013b) Cortinarius section Sanguinei in North America. Mycologia 105:344-356
Osmundson TW, Halling RE, den Bakker H (2007) Morphological and evidence supporting an arbutoid mycorrhizal relationship in the Costa Rican páramo. Mycorrhiza 17:217-222

Palfner G (2001) Taxonomische Studien an Ektomykorrhizen aus den Nothofagus-Wäldern Mittelsüdchiles. Bibl Mycol 190:1-243

Peintner U, Moncalvo J-M, Vilgalys R (2004) Toward a better understanding of the infrageneric relationships in Cortinarius (Agaricales, Basidiomycota). Mycologia 96:1042-1058

Raidl S, Scattolin L, Agerer R (2006) Cortinarius bulliardii (Pers.) Fr. + Quercus pubescens Willd. In: Agerer R, Danielson RM, Egli S, Ingleby K, Luoma D, Treu R (eds) Descriptions of ectomycorrhizae, vol 9/10. Einhorn, Schwäbisch Gmünd, pp 27-32

Rambaut A, Suchard M, Drummond A (2014) Tracer. http://tree.bio.ed. ac.uk/software/tracer/. Accessed 02 Feb 2016

Ronquist F, Teslenko M, van der Mark P, Ayres DL, Darling A, Höhna S, Larget B, Liu L, Suchard MA, Huelsenbeck JP (2012) MrBayes 3.2: efficient Bayesian phylogenetic inference and model choice across a large model space. Syst Biol 61:539-542

Seress D, Kovács GM, Jakucs E (2012) Cortinarius saturninus (Fr.) Fr. + Salix alba L. In: Agerer R, Danielson RM, Egli S, Ingleby K, Luoma D, Treu R (eds) Descriptions of ectomycorrhizae, vol 13. Einhorn, Schwäbisch Gmünd, pp 33-38

Spurr AR (1969) A low viscosity epoxy resin embedding medium for electron microscopy. J Ultrastruct Res 26:31-43

Stamatakis A (2006) RAxML-VI-HPC: maximum likelihood-based phylogenetic analyses with thousands of taxa and mixed models. Bioinformatics 22:2688-2690

Stamatakis A, Hoover P, Rougemont J (2008) A rapid bootstrap algorithm for the RAxML web servers. Syst Biol 57:758-771

Stensrud Ø, Orr RJS, Reier-Røberg K, Schumacher T, Høiland K (2014) Phylogenetic relationships in Cortinarius with focus on North European species. Karstenia 54:57-71

Suárez-Santiago VN, Ortega A, Peintner U, López-Flores I (2009) Study on Cortinarius subgenus Telamonia section Hydrocybe in Europe, with espacial emphasis on Mediterranean taxa. Mycol Res 113: 1070-1090

Uhl M (1988) Identifizierung und Charakterisierung von Ektomykorrhizen an Pinus silvestris und von Ektomykorrhizen aus der Gattung Tricholoma. Dissertation, University of Munich

Uhl M, Agerer R (1987) Studies on ectomycorrhizae XI. Mycorrhizae formed by Dermocybe crocea on Pinus silvestris and Dermocybe palustris on Pinus mugo. Nova Hedwigia 45:509-527

Uhl M, Agerer R (1988) Dermocybe crocea. In: Agerer R (ed) Colour atlas of ectomycorrhizae, plate 14. Einhorn-Verlag, Schwäbisch Gmünd

Waller K, Agerer R (1993) Ectomycorrhizen von Dermocybe cinnamomeolutea (Cortinariaceae) und Tricholoma acerbum (Tricholomataceae). Sendtnera 1:23-38

Weiss M (1988) Ektomykorrhizen von Picea abies. Synthese, Ontogenie und Reaktion auf Umweltschadstoffe. Dissertation, University of Munich

White TJ, Bruns TD, Lee SB, Taylor JW (1990) Amplification and direct sequencing of fungal ribosomal RNA genes for phylogenetics. In: Innis MA, Gelfand DH, Sninsky JN, White TJ (eds) PCR protocols: a guide to method and applications. Academic, San Diego, pp 315 322

Wiedmer E, Senn-Irlet B (1999a) Cortinarius alnobetulae Kühn. + Alnus viridis (Chaix) DC. In: Agerer R, Danielson RM, Egli S, Ingleby K, Luoma D, Treu R (eds) Descriptions of ectomycorrhizae, vol 4. Einhorn, Schwäbisch Gmünd, pp 7-12

Wiedmer E, Senn-Irlet B (1999b) Cortinarius kuehneri Mos. + Alnus viridis (Chaix) DC. In: Agerer R, Danielson RM, Egli S, Ingleby K, Luoma D, Treu R (eds) Descriptions of ectomycorrhizae, vol 4. Einhorn, Schwäbisch Gmünd, pp 25-29

Wiedmer E, Senn-Irlet B (1999c) Cortinarius atropusillus Favre + Alnus viridis (Chaix) DC. In: Agerer R, Danielson RM, Egli S, Ingleby K, 
Luoma D, Treu R (eds) Descriptions of ectomycorrhizae, vol 4. Einhorn, Schwäbisch Gmünd, pp 13-18

Wiedmer E, Senn-Irlet B (1999d) Cortinarius badiovestitus Mos. + Alnus viridis (Chaix) DC. In: Agerer R, Danielson RM, Egli S, Ingleby K, Luoma D, Treu R (eds) Descriptions of ectomycorrhizae, vol 4. Einhorn, Schwäbisch Gmünd, pp 19-23

Wiedmer E, Senn-Irlet B (2001a) Cortinarius bibulus Quél.) + Alnus viridis (Chaix) DC. In: Agerer R, Danielson RM, Egli S, Ingleby K, Luoma D, Treu R (eds) Descriptions of ectomycorrhizae, vol 5. Einhorn, Schwäbisch Gmünd, pp 23-27
Wiedmer E, Senn-Irlet B (2001b) Cortinarius helvelloides (Fr.) Fr. + Alnus viridis (Chaix) DC. In: Agerer R, Danielson RM, Egli S, Ingleby K, Luoma D, Treu R (eds) Descriptions of ectomycorrhizae, vol 5. Einhorn, Schwäbisch Gmünd, pp 29-34

Zotti M, Ambrosio E, Di Piazza S, Bidaud A, Boccardo F, Pavarino M, Mariotti MG, Vizzini A (2014) Ecology and diversity of Cortinarius species (Agaricales, Basidiomycota) associated with Quercus ilex L. in the Mediterranean area of Liguria (Northwestern Italy). Plant Biosyst 148:357-366 